\title{
INTEROFEICE MEMORANDUM
}

Date: April 13, 1989

From: T. R. Thompson $7 / 4$

To: Jim Haugen, ENG-1, MS-M721

Subject: Conceptual process description of M division incinerator project.

The conceptual flowsheet and material and energy balances are shown on LANL drawings ENG-PL-3948 sheets 1 and 2 . Sheet 1 shois the steady-state operating conditions and sheet 2 shows ti.? maximum startup conditions. The process is composed of a siza reduction by shedding step and followed by an incineration step to dispose of the shredded wood.

The shredder is a low speed $(<25 \mathrm{rpm})$ shredder that tears tine wood apart, rather than beating it apart in a hammer mill typ of size reduction device. The low speed feature will minimize the mechanical impact shock to the wood pieces and eliminate the need dust control on the shredder. The shredder is sized so that complete test stand tables $\left(4^{\prime} \times 8^{\prime} \times 2^{\prime}\right)$ can be fed. The tables are transported to the incineration site using a dump truck, or similar vehicle, and manually dumped into the shredder feed hopper. The hopper is sized to accommodate a full truck load of material. After dumping, the operator will secure tine area (no persons allowed near the shredder) and start the shredder operation from the control panel located in a remote control house. The shredder and belt conveyor both start from the same on-off switch on the control panel. The tables are reduced in size in the shredder to pieces less than 2 " $x 11 / 2$ " $x$ 24"; this is the maximum size that results when $a{ }^{2} x 4$ enters the shredder in an end-on orientation. A smaller shredder would make smaller pieces of shredded wood; however, the small is size could not handle whole test stands. The shredded wood is transferred to the live-bottom storage bin with the be:= conveyor. The shredder will operate on an as-needed basis whenever test stands are transported to the site for disposal. Throughput rate of the shredder on whole test stands is estimated to be about $1500 \mathrm{lb} / \mathrm{hr}$ via conversations with sinedde: manufactures.

The live-bottom storage bin uses a "walking floor" design for positive unloading of the shredded wood onto the transeer conveyor. This design was originated for "hog fuel" storage bins in the sawmill industry. The "hog fuel" is the part of logs that are unusable for lumber and are reduced in size using a hammer mill. The live-bottom bin will have a simple roof for

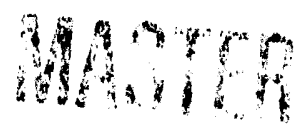

MommBution or THIS DOCIJMENT is UNUBRTER 
protecting the shredded wood from rain and snow. The bin wi:: have a usable volume of $700 \mathrm{ft}^{-3}$ for storing 1 months worth o shredded test stands $\left(10,0001 \mathrm{~b} / 15 \mathrm{lb} / \mathrm{ft}^{-3}=666.7 \leq \mathrm{t}^{-3}\right)$. The transfer conveyor can feed either the recycle conveyor or tha feed conveyor to the incinerator.

The purpose of the recycie conveyor is to allow the shredded wood to be processed again through the shredder for further size reduction. This is necessitated because the opening of the ram feeder charging hopper is about $24 " x 36 "$ on incinerazors of the size we are using. The re-shredded material is stored again in the live-bottom bin waiting incineration. This operation will be done probably once a month prior to operating the incingratoc. The use of the recycle conveyor approach is simpler than '1sing a screen to remove the oversize pieces of shredded wood from the feed to the incinerator. The majority of incinerator downtime in "hog fuel" service is feed problems; secondary shredding will eliminate the problem.

The shredded wood is incinerated in a dual chamber controlled air type of incinerator. The wood waste is batch fed to the primary chamber using an automatic ram feeder mechanism that is part of the incinerator equipment package. The feed hoppe: suppling the ram feeder is loaded with wood waste prior to $a$ charging cycle by operating the live bottom bin. transfer conveyor and incinerator feed conveyor for a preset tim: increment. The operating controls of the live bottom bin, transfer conveyor, and incinerator feed conveyor will have to ba interfaced with the ram feeder logic in the incinerator conrso: panel. The primary (lower) chamber operates in a star $:$ a $a i:=$ (sub-stoichiometric) mode to control the temperature to < ij:J degrees $F$. where the wood waste is pyrolyzed to gaseous products. The primary chamber operates in a quiescent, nonturbulent mixing mode, thereby minimizing ash entrainment in tha offgas. Carbon is removed from the asi by oxidation in the as: pile with the underfire air. The ash will stay in the priman? chamber during operation, no continuous ash removal is nezassary. Ash will be manually removed from the primary chamber and placed in a dedicated dumpster after an incineration campaign. It is anticipated that the ash can be disposed of in a landfill as it will be the same material as fireplace asi.

The primary chamber offgas passes into zhe secondary chambu: where complete oxidation taxes place. The temperature of thz secondary chamber is controlied by excess secondary air to abou: 1300 degrees $F$. A large amount of air (227.8 \% stoichiometriz total) is necessary to keep the secondary chamber temperatura to 1800 degrees $F$. because of the high heat content of the woo: waste (7382 Btu/lb at $15 \%$ moisture content).

The size of the incineracor $(400 \mathrm{lb} / \mathrm{hr})$ is set by the requiriment to contain all the ash produced from 10000 ib/month of woo: waste (134 lo ash). During normal steady-state operation, ihj 
burners for both chambers are in an "idle" state, firing a" abole 50.000 Btu/hr $(5.164$ lidhr or 0.71 gal/hr tot?: of $\#$ fuel oil in the low-fire position to serve as positive ignitic: sources. Both burners are responsible for temperature controi ci their respective incinerator chambers if conditions warzan: (wet wood, low feed rate, etc.l.

The incinerator can be operated in one continuous campaign per month of 25 hours duration to burn the monthly 10.000 ib $=$ wood. The incinerator may also be operated in a saveral da: campaign by "parking" the unit overnight in a low fire mode =conserve temperature with no wood feed.

Maximum use of fuel oil occurs during heatup immediately be wood waste feed starts. These conditions are shown in sheat.. of the drawing package. The maximum \# 2 fuel oil firing rate is $64.15 \mathrm{lb} / \mathrm{hr}(8.84 \mathrm{gal} / \mathrm{hr})$. If initial heatup from ambient to operating temperature takes 10 hours, then about 45 gal of \#2 fuel oil would be required. About 18 to 25 gal would be requires for a 25 hour operating campaign depending upon weatier conditions etc. Therefore, about 70 gal of fuel may be required per month of operation.

A brief study was made of potential gaseous emissions from the incinerator. Maximum particulate emissions occur during steady state operation and are estimated at $0.22 .35 \mathrm{ib} / \mathrm{hr}$ ash. This is based on $95 \%$ ash retention in the primary chamber with 5 being contained in the offgas and a wood ash content of $1.34 \%$, which is an average number for most woods and was obtained from Marks Mechanical Engineers Handbook, 8th ed., page 7-12. The $95 \%$ is a conservative number; the controlled air incinerator at $45 \mathrm{~S}-7$ routinely achieves $98 \%$ ash retention. Carion monoxide (CO) Nas estimated at $100 \mathrm{ppm}$ maximum immediately aiter a wood EəEI charging cycle during steady-state operation; this equals 0.521 lb colhr. The maximum sulfur dioxide (SO2) emissior.s $0=2 \cdots:$ during the maximum oil firing rate during heatup which egis:s 0.282 lo SO2/hr. All of the sulfir comes from the fuel oi: wo: normally does not have any sulfuzin it. Almost all the No: comes from Eixed nitrogen in the fuei oil $(1.265$ ib No2/: : rather than thermal Nox $(0.0024$ is No2/hr) due to the 10N (13.1) E.) operating temperature. Wood does not normally ina nitrogen component.

\section{DISCLAIMER}

This report was prepared as an account of work sponsored by an agency of the United States Government. Neither the United States Government nor any agency thereof, nor any of their employees, makes any warranty, express or implied, or assumes any legal liability or responsibility for the accuracy, completeness, or usefulness of any information, apparatus, product, or process disclosed, or represents that its use would not infringe privately owned rights. Reference herein to any specific commercial product, process, or service by trade name, trademark, manufacturer, or otherwise does not necessarily constitute or imply its endorsement, recommendation, or favoring by the United States Government or any agency thereof. The views and opinions of authors expressed herein do not necessarily state or reflect those of the United States Government or any agency thereof. 


\section{INTEROFFICE MEMORANDUM}

Date: April 27, 1989

Erom: T. K. Thompson T/7

To: Jim Haugen, ENG-1, MS-i1721

Subject: Costs of incinerator and live bottom bin.

Attached is a cost quotation on the incinerator for the $M$ division job. The estimated cost of the live bottom bin is $\$ 30.000$ obtained from telephone conversations with vendors; I have no firm written cost proposals on the bin. The bin and conveyors are in one procurement package and the vendors cannot price until we send them elevation drawings for their design efforts.

The conveyor from the shredder to the live bottom bin is $3^{\circ}$ wide and about $30^{\circ}$ long and will handle $1500 \mathrm{lbs} / \mathrm{hr}$. The recycle conveyor from the bin back to the shredder needs to be only 2' wide by about 30 ft long and handles 1500 lb/hr also. The transfer conveyor on the end 0 ' the live bottom bin is a $2^{\prime}$ ' wide by 10' long belt conveyor that is reversible. The incinerator feed conveyor is a 1 ' wide by about $15^{\circ}$ iong drag chain type that can handle about $600 \mathrm{lb} / \mathrm{hr}$ maximum. This should give you an idea of conveyor sizing for cost estimating purposes. Call if you have any other questions. I'll be back in the office on about May 10. 
TO:

T.K. Thompson, Inc. 113 Yosemite Drive White Rock, New Mexico 87544

Attention: T.K. Thompson

Reference: Wood Incinerators/Los Alamos New Mexico Ted D. Miller Reference \#8-4022
PLACE ORDER WITH:

Joy Energy Systems, Inc.

c/o Ted D. Miller Assoc., Inc. 2140 South Ivanhoe Street

Denver, Colorado 80222

h'e are plez:sd to offer our budgetary quotation for the Joy En E Series Incinerator.

We have based our selection on the following information:

1. Wood volume reduction ( $2 \times 4$ 's, plywood, pallets all shredded to approximately 2 " $\times 2$ " $\times 12$ " size)

2. 7500' elevation, outside installation

3. Operate 1 week/month - approximately $4000 \# / h r$ load rate total 10,000\#/month

4. $1800^{\circ} \mathrm{F}$. secondary chamber

5. Simple incinerator, loader, and controls

6 . 8000 BTU/\# for wood

We have selected a Model $650 E$ with SR-22H loader with the following components:

- Base Model 650E - 400\#/hour:

Modulating primary air, modulating secondary air, six (6) straight stack sections, stainless steel stack spark screen, clean out tools, operating design 8-10 hrs/day.

- E Series SR-22H Loader:

Single ram, $22 \mathrm{ft} .{ }^{3}$ capacity complete with hydraulic power pak.

- Controls:

Standard with the following modes: Warm-up, load, stop load, burner off, automatically cycles burners, blowers.

Indicator of temperature with adjustments per chamber. motor starters for incinerator and loader.

Budget Price............ \$76,500.00

F.O.B. Factory: Charlotte, North Carolina

Delivery: 12-14 weeks after approval of drawings

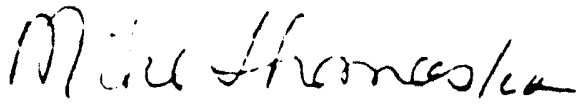

Michael A. Thomas

cc: Letter Quote-Steve Schuler Bud strope 
MODEL 650E

\section{Data}

\begin{tabular}{cccc} 
Waste Type & $\begin{array}{c}\text { (1)Auxil1ary Fuel Usage } \\
\text { BTu's/HR }\end{array}$ & $\begin{array}{c}\text { (2)Flue Gas Retention } \\
\text { Seconds } 1,800 \text { F }\end{array}$ & $\begin{array}{c}\text { (3)Burn Rate } \\
\text { Lbs./HI. }\end{array}$ \\
\hline 0 & negligible & .52 & 500 \\
1 & negl1g1ble & .55 & 650 \\
2 & 226,363 & .85 & 650 \\
3 & $1,097,127$ & .99 & 585 \\
4 & $1,500,278$ & 1.21 & 520
\end{tabular}

Heat Release Capacity $=4,225,000$ BTU/HR

Specific Heat Release $=15,089 \mathrm{BTU} / F T^{3} / \mathrm{HR}$

\begin{tabular}{lcc} 
Physical Properties & Primary Chamber & Secondary Chamber \\
\hline Volume & $220 \mathrm{FT}^{3}$ & $60 \mathrm{FT}$ \\
Refractory & $4 \mathrm{in.}$ & $4 \mathrm{in}$. \\
Refractory & $2,5000 \mathrm{~F}$ & $2,5000 \mathrm{~F}$ \\
Insulation & $1-1 / 2 \mathrm{in.}$ & $1-1 / 2 \mathrm{in}$. \\
Shell & $3 / 16 \mathrm{in}$. & $3 / 16 \mathrm{in}$. \\
Charging Door & $24 \times 24 \mathrm{in}$. & $\mathrm{N} / \mathrm{A}$ \\
Cleanout Door & $32 \times 45 \mathrm{in}$. & $\mathrm{N} / \mathrm{A}$ \\
Viewport & Optional & Optional \\
Modulated Alr & Optional & Optional \\
Type K Controller & Yes & Yes
\end{tabular}

(1) Auxiliary fuel is estimated, based on type of waste and proper operation of equipment. Auxillary fuel usage is not guaranteed.

(2) Flue gas retention times for Type 2, 3 and 4 waste include flue gas from auxiliary fuel input.

(3) This is the actual burn rate. Incinerator may be charoed at a greater rate when allowance is made for burn down time. 


\section{B-SBRIBS INCINBRATORS}

\section{Notes}

\section{(1) Incinerator Base Price:}

The base price includes the incinerator complete, with refractory, burners, blowers, NEMA 12 control panel, two (2) Type $R$ thermocouples, two (2) programmable temperature controllers, modulated secondary air, pushbutton start/stop, shutdown timer and a $24^{\prime \prime} \times 24^{\prime \prime}$ charging door built into a large cleanout door. The $100 \mathrm{E}$ through $300 \mathrm{~B}$ have $24^{\prime \prime} \times 33^{\prime \prime}$ cleanout doors and the $480 \mathrm{~B}$ through $780 \mathrm{~B}$ have $32^{\prime \prime} \times 45^{\prime \prime}$ cleanout doors. Each chamber has a 3" viewport without a blastgate. The $480 \mathrm{~B}$ through $780 \mathrm{~B}$ have separate blowers for primary and secondary air supply. The 100B throush $300 \mathrm{~B}$ have a single blower to supply both primary and secondary air.

(q) Pathological Option:

The pathologichl option includes a "pathmode" switch and controls for the $100 \mathrm{~B}$ and $1 \mathrm{KOB}$. The pathological option includes "pathmode" switch, controls and an increased burner gapacity for the $300 \mathrm{~B}$. The $480 \mathrm{E}$ through $7 \beta 0 E$ receive a "pathmode" switch, cpntrols and an additional primary burner with this pption. Primary gas bunners supplied with the pathological option are as fol Lows:

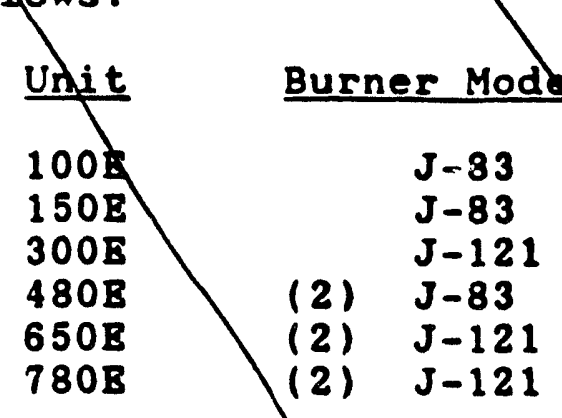

The pathological option should be selected when burning waste which has moisture content ifeater than $70 x$ (i.e., Type 3 and type 4 waste).

\section{(3) Outside Installation:}

The standard outside installation option includes weather hoods for the burners, weatherproofing kits for damper motors, a panel heater, and a NEMA 3R control panel. The panel includes a drip shield and the temperature controllers are mounted inside the panel behind a plexiglags window. 
(4) Modulated Primary Air:

Bffective

$5-1-88$

Modulated primars air automatically controls the flow of combustion air to the primary chamber, based on primary chamber temperature, by decreasing air supply as temperature increases and increasing air supply as temperature decreases. The intent is to maintain substochiometric conditions in the primary chamber. Modulated primary air includes a motor to modulate the primary air valve.

(5) Modulated Secondary Fuel:

Rather than having an on-ofe operation the secondary burner will modulate to maintain the temperature in the secondary chanber at the set point. This option includes an additional prosrammable temperature controller. It does not include an additional thermocouple.

(6-8) Stack Options:

The incinerator base price does not include the stack. Each stack section is four feet lons. A minimum of sixteen feet of stack should be used for proper draft. Stack sections may be ordered with drawbands or flanges. Test ports are inoluded. Please be sure to take into account seographical elevation and add twents inches of stack for each $1000 \mathrm{ft}$. above sea level. Do not use over twenty feet of stack without consulting the factors for pricing, Please refer to the attached information about altitude correction factora.

(9) Spark Screen:

E-Series spark screens are manufactured fron $316 \mathrm{~L}$ stainless steel, per NFPA code requiraments.

(10) Cleanout Toola:

The cleanout tools include a hoe, a slice bar and a no. 8 coal scoop. Some specifications require these tools. 
13) One second Retention:

The secondary chamber volumes 11 sted below will provide one

second retention based on burning type 1 waste at $1,80 Q^{\circ} F$ and at the rated capadity of the unit. This option includes a modulated secondar burner sized to achieve $1,800 \cdot \mathrm{F}$ prior to chatging waste. High temperature $(2,800 \cdot \mathrm{F})$ refractory is also included.
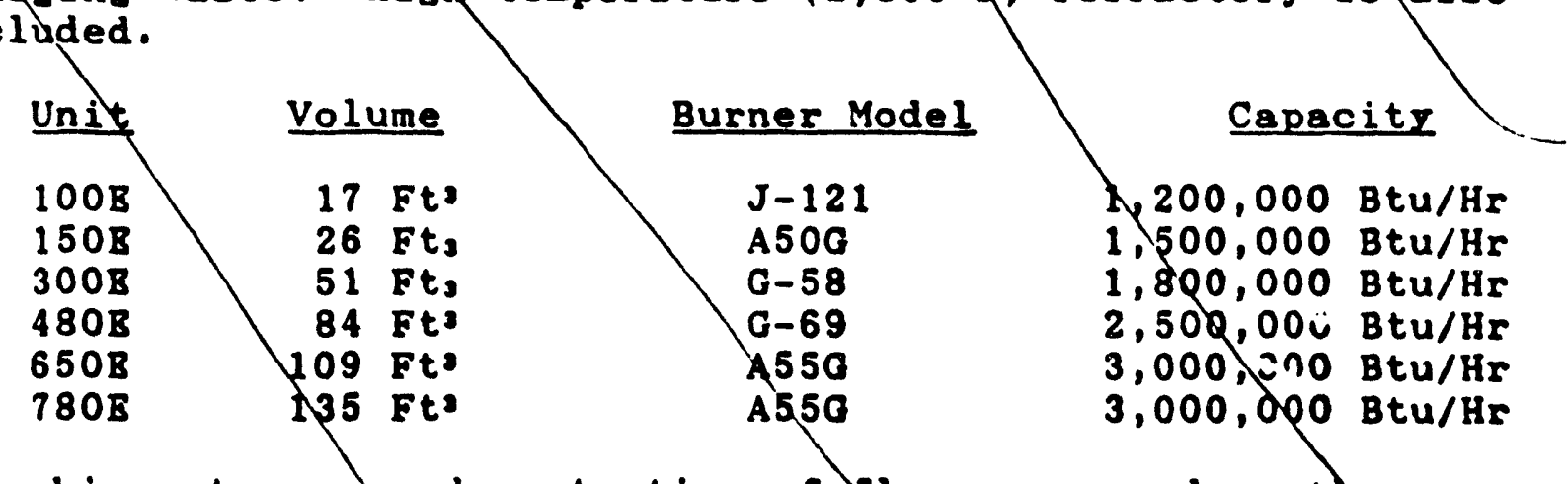
waste charging rate to onchalf of fun capacity. If this is not Peasible, louble the price for one second retention and maintain the standard rated capacity.

\section{(A) Tydraulic Loader Base Price:}

The Model SR-6M loader is for use on applications where the customer does not want the operator exposed to the fire while loading a manually-fed incinerator, but is unwilling to pay for a hydraulic loader. The loader has the same sequence of operation as a hydraulic loader. However, all operations are manual. The guillotine charging door is operated by as manual crank and the ram has a tee handle to push in for chargins and pull out for retracting. The base price for the SR-12H through SR-37H includes the loader with hydraulio power pack, charging door, hydraulic hatch, flame detection, water spray and manual override controls.

(B) Cart Dumper:

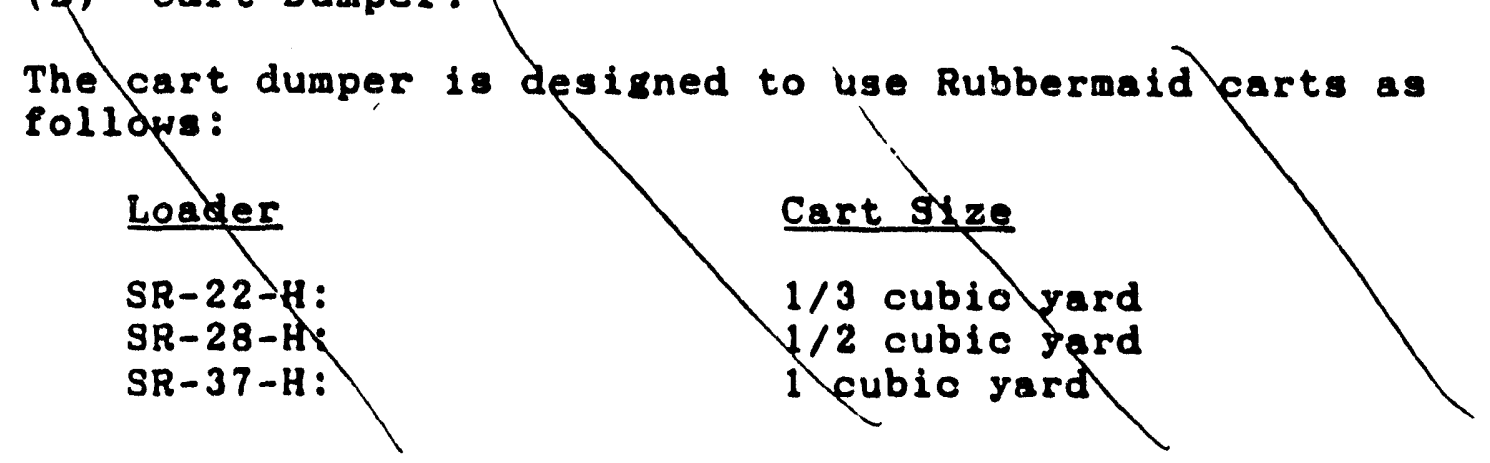




\section{' ECOLAIRE COMBUSTION PROLUCTS,INC.}

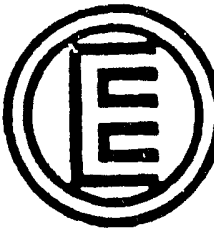

P O. Box 240707

Charlotte, North Carolina 28224

\section{TERMS AND CONDITIONS OF SALE}

This proposal. submitted by Ecolare Combustion Products, Inc. ("Company") in response 10 your request for quotation and the Company's offer to sell the equipment described herein. is subject to the Terms and Conditions stated herein. The Company hereby gives notice of its objection to any addition or different Terms contained in your request for quotation or purchase order. In the event the Purchaser issues a letter of authorization to pro. ceed or purchase order number for the intended to be covered by inis proposal prior to the execution of a definitive contract cover. ing the subject matter of this proposal, it shall be understood that the Company's proceeding under such authorization shall be in accordance with the Terms and Conditions contained herein.

1.0 PAYMENTS: Unless otherwise stated in the proposal, terms of payment shall be net casn within thiny $(30)$ days of presenta. tion of invoice with bill of lading. All payments shall be made without discount in U.S. currency. The Company is authorized to make partial shipments, and prorata payments shall be made atter receipt of any such partial shipment. If delivery is prevented or postponed by Purchaser, then all dates of payment related to delivery shall relate instead to the date of completion of manulacture.

2.0 SHIPMENTS AND DELIVERY: The Company shall use its reasonable efforts to meet all shipment or delivery dates stated herein or in Purchaser's order, but any such dates are estimates only and are not guaranteed. Company shall have no liability to Purchaser for damages or penalties, direct or indirect, for any delay in shipment or delivery. whether such delay is minor or substan. tıal. nor shall Purchaser have the right to declare a breach of con. tract because of any such delay. Delivery schedules are subject to prompt receipt by Company of all necessary information and insiructions from Purchaser. including any required approval of drawings

3.0 TITLE: Title and risk of loss or damage to the Equipment shall pass to the Purchaser upon tender of delivery F.O.B. manutac. turing lacility unless otherwise stipulated in this contract, except that a security interest in the Equipment or any replacement shall remain in the Company, regardless of mode of aracnment to realty or other proferty. until full payment in cash has been made therefore

Purchaser agiees upon request to do all things and acts necessary 10 perfect and mainiain said security interest and shall protect Company's interest by adequately insuring the Equipment aganst loss or damage from any cause wheren the Company shall be named as an additional insured

4.0 TAXES: The price Joes not include any Federal. State or local property, license. privilege. sales. use, excise. gross receipts or other like taxes which may be now or hereatter applicable 10. measured by. or imposed upon or with respect to this transac. tion. the Equipment. its sale. its value or its use, or any serix 35 pertormed in connection therewith. Such taxes will be itemized eparately to Purchaser. who shall make prompt payment to the jompany The Company will accept a valid exemplion certificate liom Purchaser. if apolicable it an exemption ceniticate previously accep!ed by ine Company is not recognized by ine governmen. ial taxing authorily involved. Purchaser agrees 10 promplly reim. ourse ine Combany for any laxes covered by such exempion cer. - ieale which the Company is required to pay.
5.0 WARRANTY: All equipment of the Company's manulacture is warranted to be free of original defects in material and workman. ship for a period of one year atter the date of installation or two years atter the date of delivery, whichever is earl:er. The Company's obligation under this warranty is strictly limited to repairing or replacing tree of charge F. O.B. factory or repair tacility any such defeclive material reported to the Company within the aforesaid period. provided Purchaser gives prompt written notification of such defects and returns the defective parts freight prepaid tor examination. The Company will not be responsible for the effects of abra. sion, corrosion, erosion or fouling of the Equipment by any foreign substance that may be deposited therein or thereon or for any damages resulting from handling. storage, installation or failure to follow good industry practices and the specific recommendations of the Company regarding the operation and maintenance of the Equipment.

The Company shall not be liable for any costs related to the repair, replacement or adjustment of the Equipment incurred by Purchaser without the Company's prior written approval. Warranty on Equipment not of the Company's manufacture is limited to the warranty extended to the Company by the manutacturer.

THE FOREGOING IS IN LIEU OF ALL OTHER WARRANTIES EITHER EXPRESSED OR IMPLIED. THE COMPANY EXPRESSLY DISCLAIMS THE IMPLIED WARRANTIES OF MERCHAN. TABILITY AND FITNESS FOR A PARTICULAR USE

6.0 LIMITATION OF LIABILITY: In no event shall the total liability of the Company arising out of the performance or breach of this agreement, whether based on contract, warranty, negilgence, in. demnity, strict liability or otherwise, exceed the purchase price of the unt of Equipment upon which such liability is based.

The Company shall in no event be liable tor any consequential. incidental, indirect. special or punitive damages arising out of this Agreement or any breach thereof. or any defect in the Equipment purchased hereunder, whether based upon lost profits or revenue. work stoppage, impairment of other goods. loss by reason of shutdown or non-operation or increased expenses of operation or otherwise, whether or not such loss or damage is based on contract, warranty, negligence, indemnity, strict liability or otherwise. 7.0 CHANGES: Purchaser may request alterations or changes in the design of the Equipment from lime 10 time. provided the requested changes are capable of being readily incorporated in the Equipment offered by the Company hereunder. If such changes affect the price or delivery of the Equipment. Purchaser will be so notified. The Company will only proceed with such changes upon receipl of a wrtten change order from the Purchaser specitying the change and the agreed revision to the price and the delivery schedule.

8.0 FORCE MAJEURE: Notwithstanding any other provision of the agreement to the contrary, the Company shall not be liable for any costs or damages for falure or delay in delivering if Equipment for reasons beyond the reasonable control of the Company, including but not limited to war, riots. civil insurrection fire, flood. strikes or other labor disturbances, acts of civil or military authori. ty including governmental laws, orders. priorities or regulations. acts of the Purchaser, embargo, delays or inability to obtain transportation and inability to obtain necessary labor or materiais. 
9.0 PATENT INDEMNITY: The Company warrants inat ine Equipment purchased hereunder shall, at the time of delivery. be free of ine valid claim of any third person by way of iniringement of any United States patent subject to the following. Purchaser agrees inat Company has the right 10 defend. or at its option 10 settle. and Company agrees. at its own expense to settle or detend any such claim. sult or proceeding brought against Purchaser. Com pany agrees to pay. subject to the limitations set forth in this paragraph, any final judgment entered against Company on such issue in any such sult or proceeding. provided Purchaser promplly notifies the Company in writing of any such claim, suit or proceeding and at Company's expense. gives Company proper and full information and assistance to settle or defend any such claim. sult or proceeding. It the goods furnished hereunder become the subject of any claim. sult or proceeding. for infringement of any patent. or in the event of any adjudication that such goods infringe any United States patent, or it the use, lease or sale of such goods is enjoined. Company may at its option and its expense (1) procure for Purchaser the right under such patent to use. lease or sell the subject goods. or (2) replace the subject goods. or (3) modity such goods. or (4) remove such goods and refund the aggregate payments and transporation costs paid therelor by Purchaser, less a reasonable sum for use. damage and obsolescence. Company shall have no liability for any infringement arising from (a) the combination of such goods with any other product or pan not furnisheo to Purchaser by Company. or (b) the modification of such goods unless such modification was made by Company. or (c) the use of such goods in practice of a process of (d) the furnishing to Purchaser of any information dala. service or ap. plication assistance. Purchaser shall nold Company narmiess against any expense. judgment or loss from intringement of any patents which results from Company's compliance with Pur. chaser's special design. specifications or instructions Company shall not be liable for any costs or expense incurred without Com. pany's written authorization.

10.0 SUSPENSION: Upon prior written notice. Purchaser may suspend the Company's work or extend schedules for up to one year, or as otherwise mutually agreed. for all or any portion of the goods and services to be furnished pursuant to this contract. In the event of any such suspension or termination. the Company shall submit its invoices for charges incurred to date plus applicable overnead and profit. which involce shall be paid bv Purchaser withın 30 days of receipt. If not applicable to the prices quoted nerein prior to such suspension or extension. the prices shall become subject to escalation from the date of the original order. in accordance with the Company's standard escalation provision. 11.0 ACCEPTANCE: The Company shall not be bound by any contract until approved in writing by an officer. The contract. when so approved. shall supersede all previous communications, elther oral or written. No modification shall be binding ucon the parties unless such modification shall be in writing. duly executed by the Purchaser and approved by an officer of the Company. 12.0 GOVERNING LAW: The rights and obligations of Purchaser and the Company shall be governed by the laws of the State o1 North Carolina. 
$10 x$ of the contract amount shall accompany the buyers purchase order.

$10 x$ of the contract amount will be invoiced with engineering submittals and will be due and pagable upon receipt of invoice.

$75 \%$ of the contract amount will be invoiced as three (3) equal progress payments of $25 x$ of the contract amount each and will be due and payable upon receipt of invoice and prior to shipment.

5\% of the contract amount will be invoiced at the time of shipment and will be due and payable upon receipt of invoice.

Should the equipment offered in this proposal be purchased for resale, the buyer's payment to the seller will not be dependent upon the buyer's receipt of payment on resale.

The price for the equipment and services offered in this proposal is based on the above terms of payment. Any deviation from these terms of payment may result in a correspondins price adjustment.

All invoices which are outstanding and unpaid for more than thirty (30) days will be subject to a late charse of $1.5 \%$ per month for at the hishest amount or rate which under applicable law buyer may contract to pay in order to induce prompt payment, whichever is less).

The seller takes exception to any and all retainage or liquidated damages. 


\section{ECOLAIRE COMBUSTION PRODUCTS, INC.}

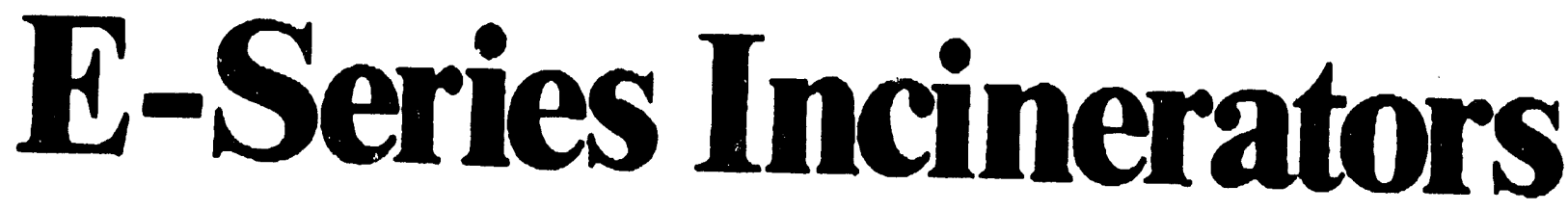

\section{Compact.Versatile. Economical.}

Ecolaire's E.Scries incineralors ace small in every way except performance!

They're ideal incinerators for small 10 medium industrial, commercial and institutional applicalions which must meet rigid pollution standards. They te easy to operate...and easy to maintain.

\section{1.. Dual Chamber Combustion}

The E-Scries Incineratop fealurcs the ame proven two. chamber combustion principle as used on larger Ecolaire T-Series. Two-shamber combustion helps assure that all combustibles are reduced to an exhaust gas that mects applicable pollution standards. Automatic controls maintain safe. dependable performance.

\section{Material Loading}

E-Serics Incinerators arc available with the type of waste loading system that best suits your requirements: Manually fed hoppere. automatic hydraulic systems, or manual loading.

\section{The Price Is Right}

E-Series Incinerators from Ecolaire bring safe, clean incineration within the budget of practically any busincss. Write loday for a quotation on the E.Series Incinerator that solves your waste handling problems. Models are available for either oil or gas firing.

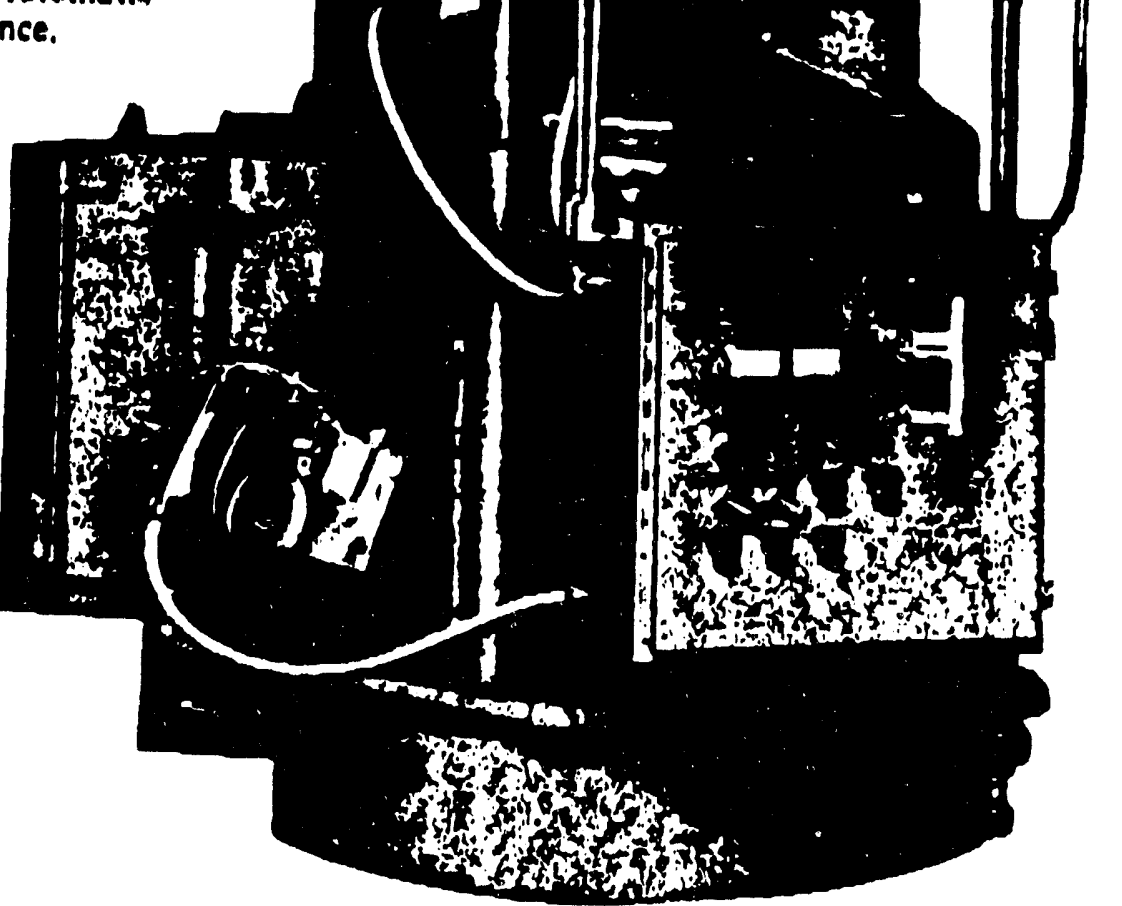




\section{E-SERIES}

Burning Rates for E.Series Inclnerators* (Lbs./Hr.)

\begin{tabular}{|c|c|c|c|c|c|}
\hline Model No. & Type 0 & Typo 1 & Type 2 & Type 3 & Type 4 \\
\hline $\begin{array}{l}100 E \\
150 E \\
300 E \\
480 E \\
650 E \\
780 E\end{array}$ & $\begin{array}{r}75 \\
115 \\
230 \\
385 \\
500 \\
610\end{array}$ & $\begin{array}{l}100 \\
150 \\
300 \\
500 \\
650 \\
800\end{array}$ & $\begin{array}{l}100 \\
150 \\
300 \\
500 \\
650 \\
800\end{array}$ & $\begin{array}{r}90 \\
135 \\
. \quad 270 \\
. \quad 450 \\
. \quad 585 \\
\quad 720\end{array}$ & $\begin{array}{r}80 \\
120 \\
240 \\
400 \\
520 \\
640\end{array}$ \\
\hline
\end{tabular}

- Burning rates were determined by tests conducted by an independent testing laboratory in accord. ance with the Federal Environmental Protection Agency standards.

Units can be charged at a rate $25 \%$ above those shown when allowance is made for burn down time.

Dimensions and Weights for E-Series Incinerators

\begin{tabular}{|c|c|c|c|c|c|}
\hline Model No. & A & $B$ & C & Stack O.D. & $\begin{array}{c}\text { Approx. Wt. } \\
\text { (Lbs.) }\end{array}$ \\
\hline $\begin{array}{l}\text { 1OOE } \\
150 E \\
300 E \\
480 E \\
650 E \\
780 E\end{array}$ & $\begin{array}{c}7^{\prime} 2^{\prime \prime} \\
77^{\circ} \\
93^{\prime \prime} \\
11^{\prime \prime} 3^{\prime \prime} \\
13^{\prime \prime} 7^{\prime \prime} \\
14^{\prime} 7^{\prime \prime}\end{array}$ & $\begin{array}{c}3^{\prime} 9^{\prime \prime} \\
4^{\prime} \\
5^{\prime} \\
6^{\prime} \\
7^{\prime} \\
7^{\prime} 6^{\prime \prime}\end{array}$ & $\begin{array}{l}6^{\prime} 3^{\prime \prime} \\
6^{\prime} 8^{\prime \prime} \\
76^{\prime \prime} \\
8^{\prime} 6^{\prime \prime} \\
9^{\prime} 2^{\prime \prime} \\
10^{\prime} 7^{\prime \prime}\end{array}$ & $\begin{array}{c}16^{\prime \prime} \\
16^{\prime \prime} \\
18 \mathrm{~K}^{\prime \prime} \\
26 \mathrm{~K}^{\prime \prime} \\
31 \mathrm{~K}^{\prime \prime} \\
33 \mathrm{~K}^{\prime \prime}\end{array}$ & $\begin{array}{r}6,000 \\
7,300 \\
9,800 \\
16,000 \\
23,000 \\
28,600\end{array}$ \\
\hline
\end{tabular}

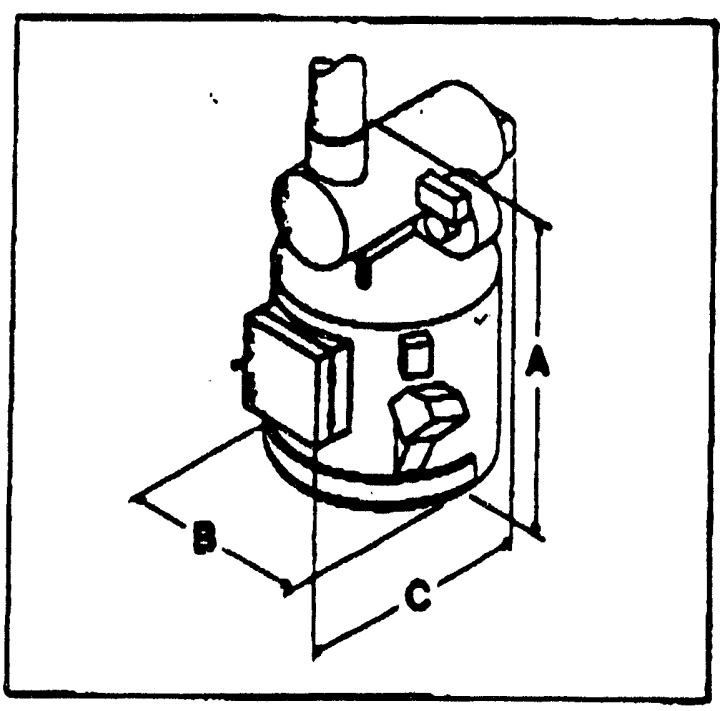

Models 100E inru 780 E

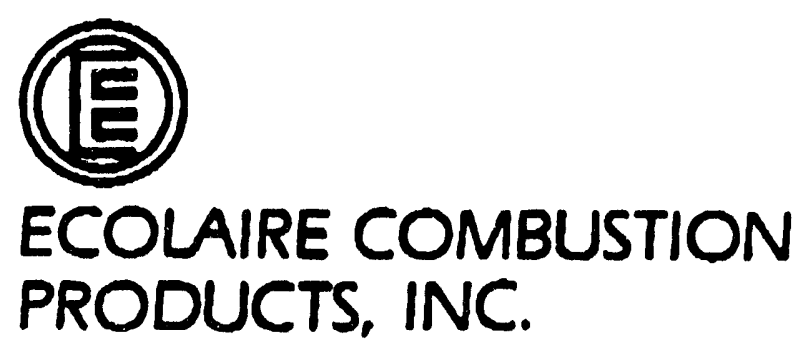

11100 Natlons Ford Rd.

P.O. Box 240707, Charbere, NC 28224

Phone: 704-588-1620 Telex 572.549 
MODEL $650 E$

\section{Deta}

\begin{tabular}{|c|c|c|c|}
\hline Waste Type & $\begin{array}{c}\text { (1) AUX111agy Fuel Usage } \\
\text { BTU's/HR }\end{array}$ & $\begin{array}{l}\text { (2)Flue Gas Retention } \\
\text { Seconds } 1,8000 F \\
\end{array}$ & $\begin{array}{l}\text { (3) Burn Rate } \\
\text { Lbs./Hr. }\end{array}$ \\
\hline 0 & neg119101e & .32 & 500 \\
\hline 1 & negllglble & .35 & 650 \\
\hline 2 & 226,363 & .85 & 630 \\
\hline 3 & $1,097,127$ & .99 & SAS \\
\hline 4 & $1,500,278$ & 1.21 & 520 \\
\hline
\end{tabular}

Heat Release Capaclty = 4,225,000 BTU/HR

Speclile Heat Release = 13,089 BTU/FT3/HR

\begin{tabular}{lcc} 
Physleal Properties & Primasy Chamber & Secondary Chamber \\
\hline Volume & $220 \mathrm{FT}^{3}$ & $60 \mathrm{FT}$ \\
Refractory & $4 \mathrm{ln}$. & $4 \mathrm{In}$. \\
Refractory & $2,5000 \mathrm{~F}$ & $2,3000 \mathrm{~F}$ \\
Insulation & $1-1 / 2 \mathrm{ln}$. & $1-1 / 2 \mathrm{ln}$. \\
Shedl & $3 / 16 \mathrm{ln}$. & $3 / 16 \mathrm{ln}$. \\
Charglng Door & $24 \times 24 \mathrm{ln}$. & $\mathrm{N} / \mathrm{A}$ \\
Cleanout Door & $32 \times 451 \mathrm{n}$. & $\mathrm{N} / \mathrm{A}$ \\
Vlewport & Optlonal & Optlonal \\
Modulated Alr & Optlonal & Optlonal \\
Type K Controller & Yes & Yes
\end{tabular}

(1) Aux111ary puel is estimated, based on type of waste and proper operation of equipment. Auxlliary fuel usage is not guaranteed.

(2) Flue gas retention times for Type 2, 3 and 4 waste Include plue gas from auxl11ary fuel input.

(3) This is the actual burn rate. Inclnerator may be charged at a greater rate when allowance is made for burn down time. 


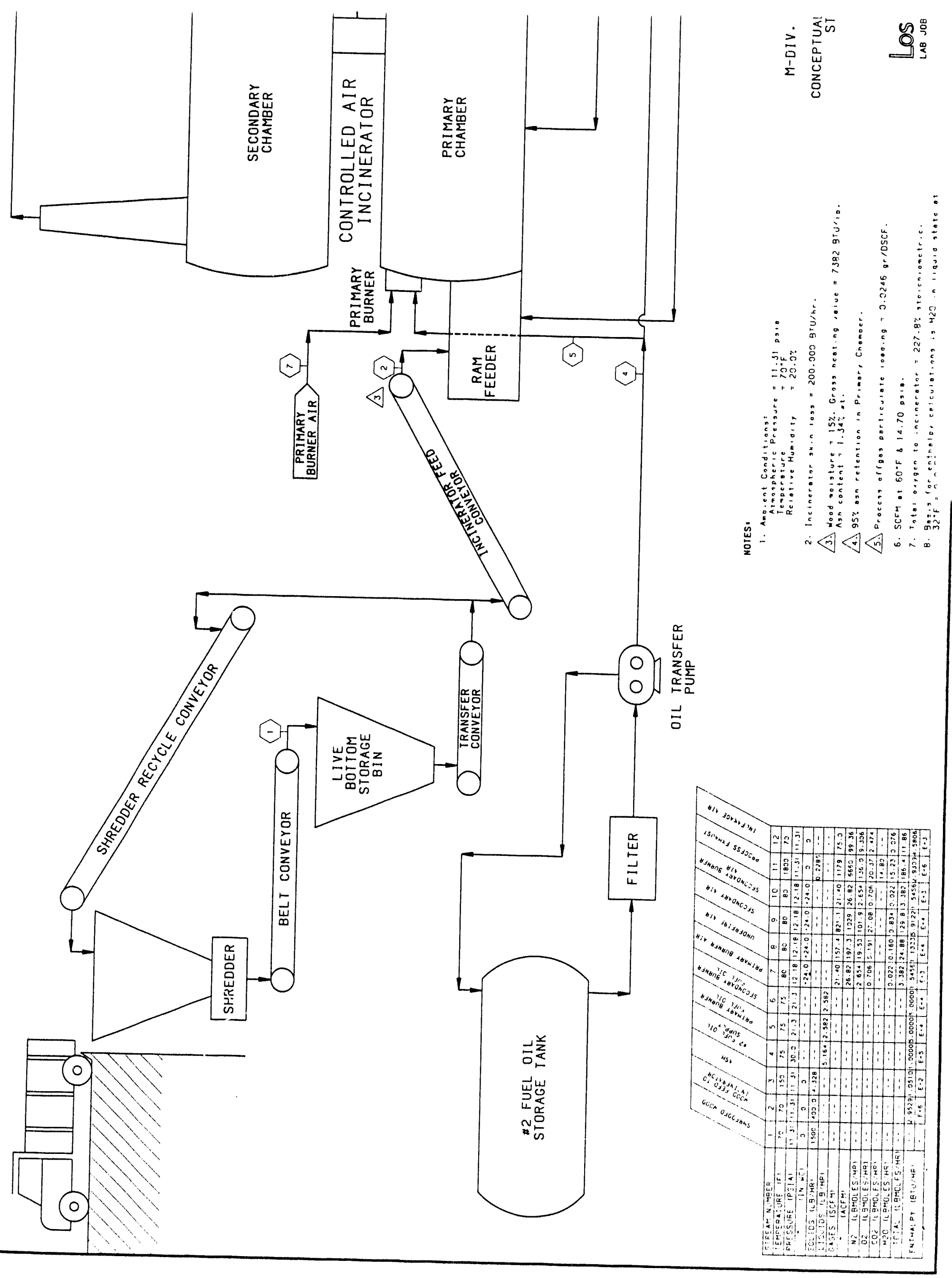




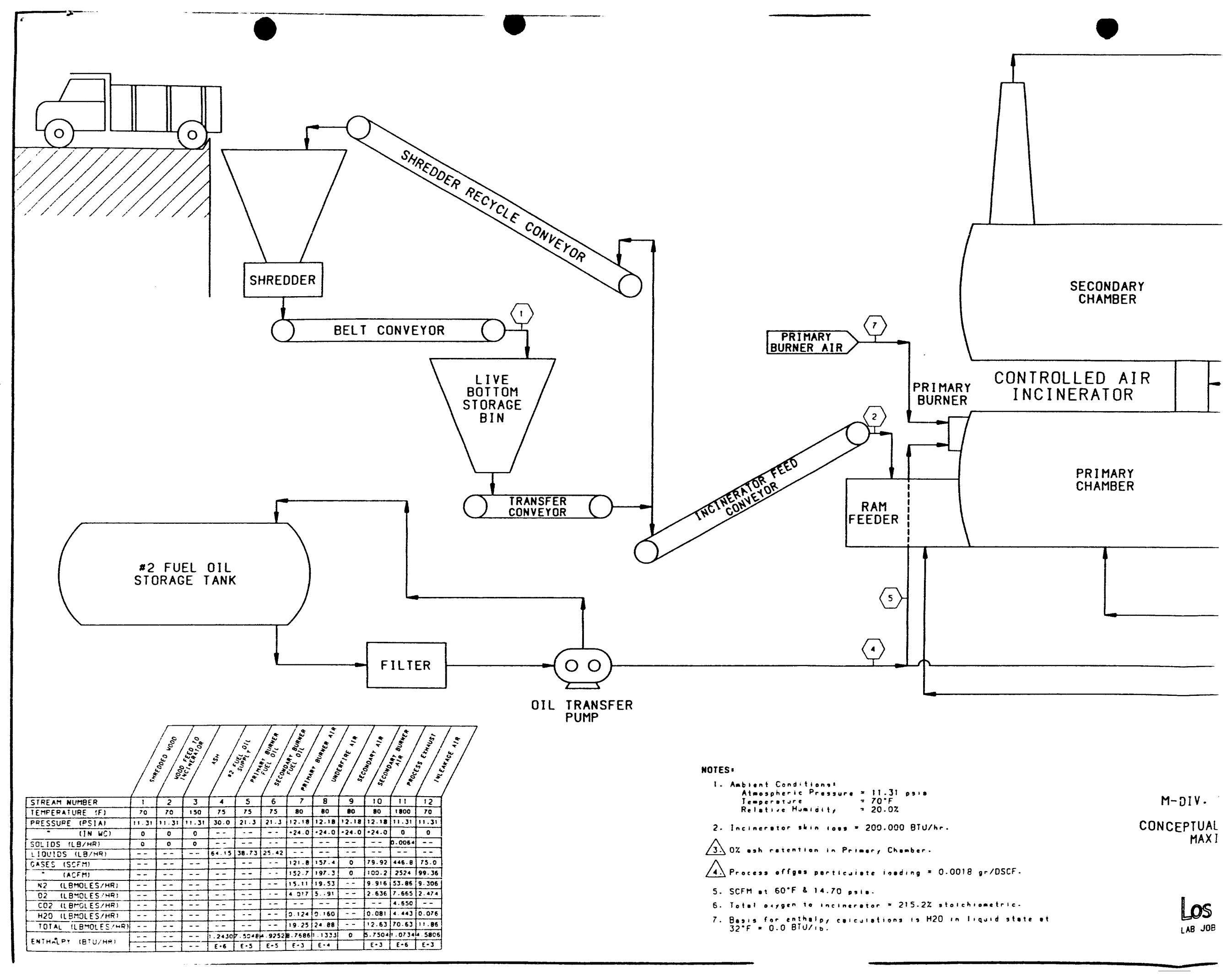




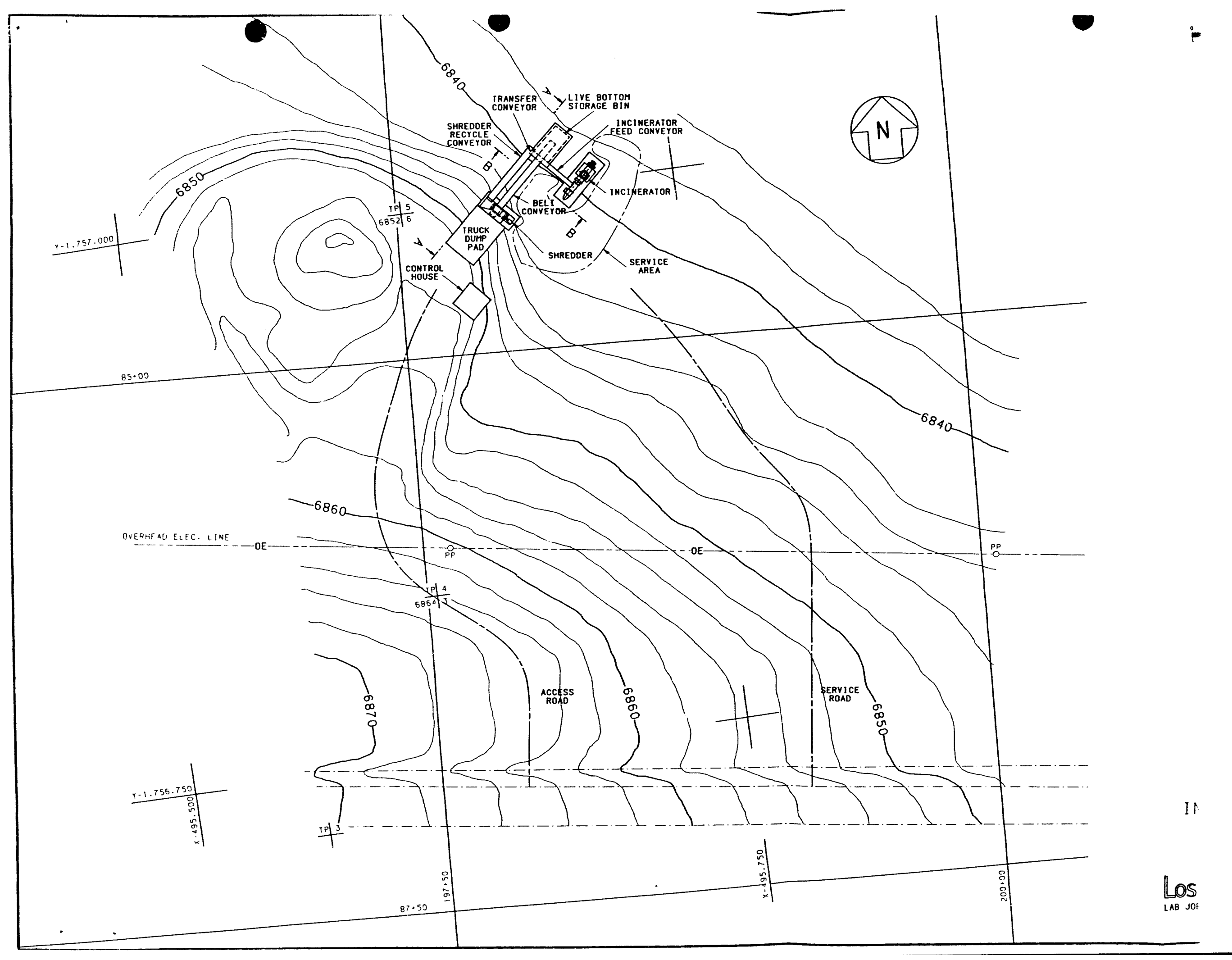




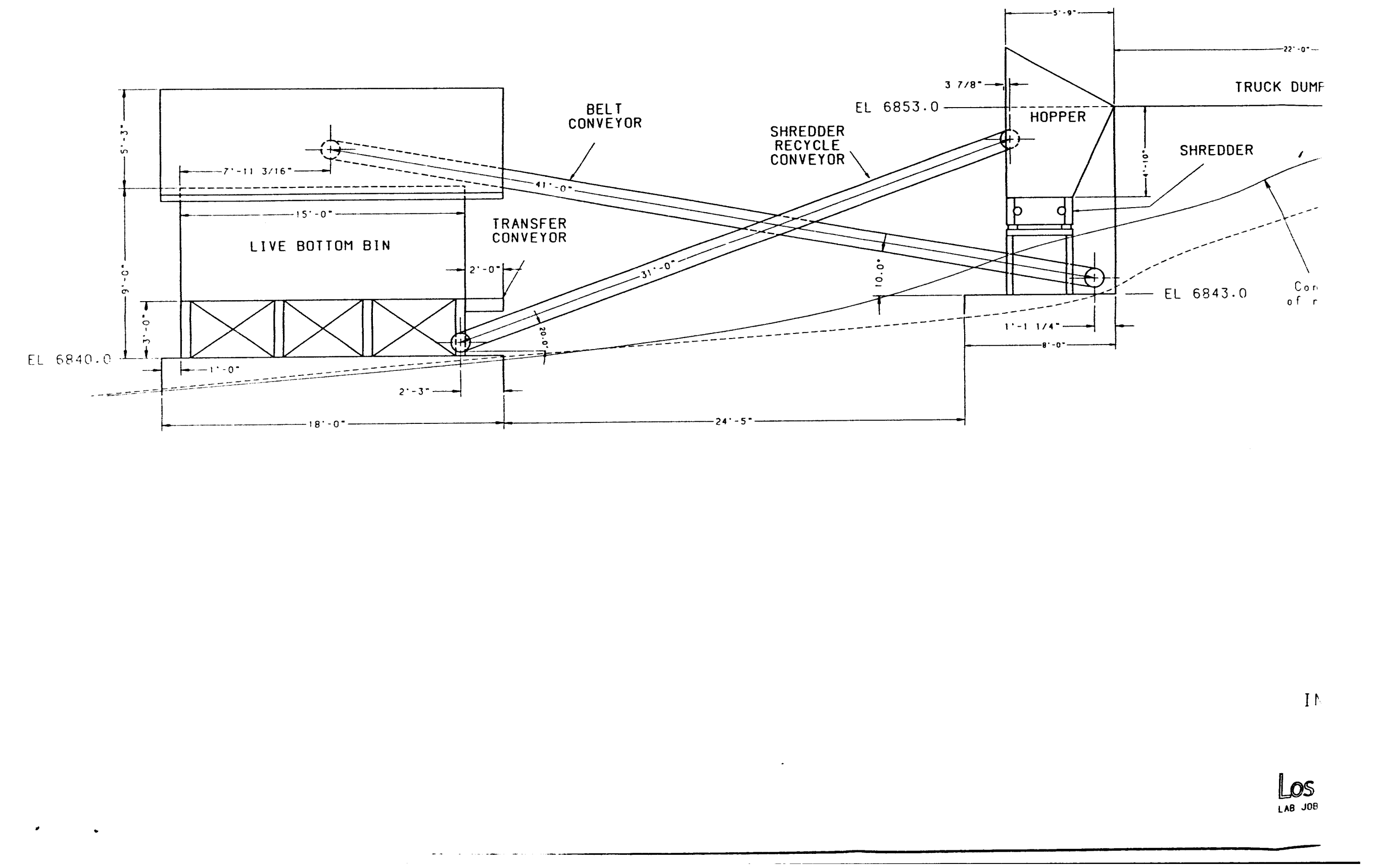




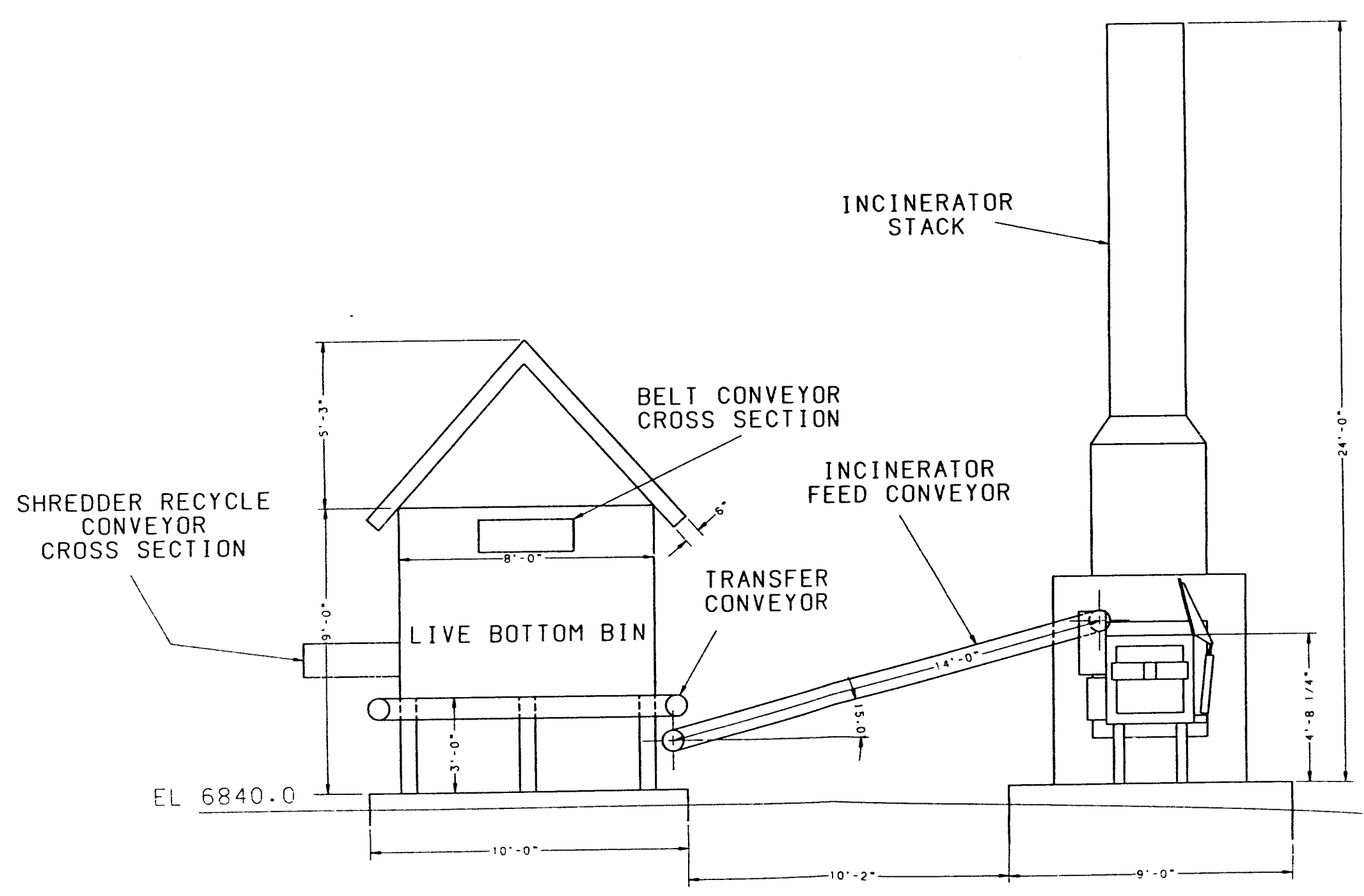



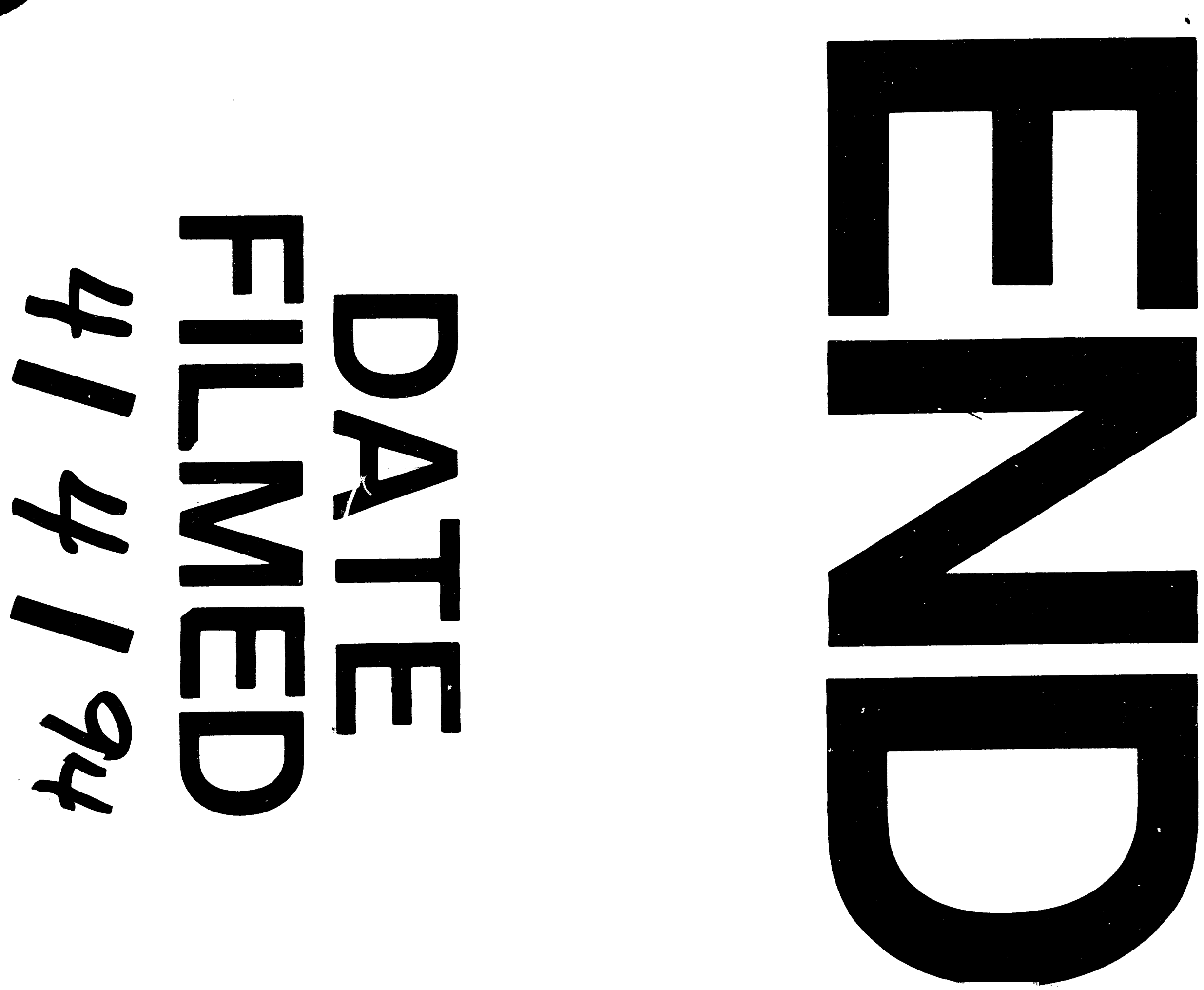
